\title{
DINAMIKA SUHU PERMUKAAN DAN KERAPATAN VEGETASI DI KOTA CIREBON
}

\author{
Moh. Dede ${ }^{I^{*}, \text { Galuh Putri Pramulatsih }}{ }^{1}$, Millary Agung Widiawaty, \\ Yanuar Rizky Ramadhan', Amniar Ati ${ }^{3}$ \\ ${ }^{1}$ Departemen Pendidikan Geografi, FPIPS, Universitas Pendidikan Indonesia \\ ${ }^{2}$ Program Studi Meteorologi, FITB, Institut Teknologi Bandung \\ ${ }^{3}$ Program Studi Pendidikan Geografi, Sekolah Pascasarjana, Universitas Pendidikan Indonesia \\ *Email :m.dede.geo@gmail.com
}

\begin{abstract}
ABSTRAK
Peningkatan suhu udara merupakan dampak dari pemanasan global serta berkurangnya vegetasi. Pada kawasan perkotaan, peningkatan suhu udara secara signifikan dapat memunculkan fenomena urban heat island yang dalam jangka panjang mampu mengubah iklim mikro. Estimasi suhu permukaan dan kerapatan vegetasi diperoleh dari data satelit penginderaan jauh secara multi-temporal. Penelitian ini bertujuan untuk menganalisis dinamika suhu permukaan dan kerapatan vegetasi di Kota Cirebon. Penelitian ini memanfaatkan data citra Landsat-5 TM dan Landsat-8 OLI yang divalidasi dengan data MODIS pada periode tahun 1998, 2008, serta 2018. Nilai suhu permukaan diekstraksi dengan radiative transfer equation, sedangkan informasi kerapatan vegetasi diperoleh dengan normalized difference vegetation index (NDVI). Interaksi antara suhu permukaan dan kerapatan vegetasi diketahui melalui analisis korelasi spasial. Sepanjang tahun 1998 hingga 2018 terjadi peningkatan suhu permukaan sebesar $1.18^{\circ} \mathrm{C}$ yang disertai dengan menurunnya area bervegetasi rapat hingga $12.683 \mathrm{~km}^{2}$. Penelitian ini juga menunjukkan korelasi negatif yang signifikan antara suhu permukaan dan kerapatan vegetasi di Kota Cirebon. Suhu permukaan tertinggi terpusat pada CBD, pelabuhan, area rawan kemacetan, kawasan industri, dan terminal. Berdasarkan kajian ini, upaya menanggulangi suhu permukaan di Kota Cirebon perlu ditangani melalui penyediaan ruang terbuka hijau, green belt, maupun reforestrasi.
\end{abstract}

Kata kunci: kerapatan vegetasi, Kota Cirebon, penginderaan jauh, suhu permukaan

\begin{abstract}
Increasing air temperature is the effects of global warming and vegetation reduced. In urban area, significant increasing of air temperature rises urban heat island phenomenon which in long term is able to change the microclimate. Estimation of land surface temperature (LST) and vegetation greenness are obtained from multitemporal remote sensing satellite data. This study aims to analyse the dynamics of LST and vegetation greenness in Cirebon City. This study utilises Landsat-5 TM and Landsat-8 OLI imagery data which are validated with MODIS data in the 1998, 2008 and 2018. The LST value extracted using radiative transfer equation, while vegetation density information is obtained by normalized difference vegetation index (NDVI). The interaction between LST and vegetation greenness is known through spatial correlation analysis. During 1998 to 2018, LST is increased of $1.18^{\circ} \mathrm{C}$, while high greenness vegetation area decreased reach $12.683 \mathrm{~km}^{2}$. This study also showed significant negative correlation between LST and vegetation greenness in the Cirebon City. The highest of LST distribution is concentrated in CBD, harbour, traffic jam zone, industrial estates and terminals. Based on this study, the effort of LST management in the city needs provision of green open space, green belt and reforestration.
\end{abstract}

Keywords: Cirebon City, land surface temperature, remote sensing, vegetation greenness 


\section{PENDAHULUAN}

Dampak negatif perkembangan kawasan perkotaan dan industrialiasi adalah menurunnya kualitas lingkungan yang memicu terjadinya peningkatan suhu udara (Zarzoso dan Maruotti, 2011). Bila dibandingkan dengan faktor alamiah, beragam aktivitas manusia memiliki peran yang lebih besar dalam meningkatkan temperatur dan pelepasan gas rumah kaca (Nandi dan Dede, 2019). Peningkatan suhu udara juga dipicu oleh laju konversi lahan yang menyebabkan berkurangnya lahan bervegetasi rapat (Zhang dkk.; Lin dkk., 2016). Seiring berjalannya waktu, peningkatan temperatur secara signifikan dapat memunculkan fenomena urban heat island yang mengubah pola iklim mikro, konsumsi sumber daya, dan gaya hidup masyarakat (Utomo dkk., 2017).

Peningkatan suhu udara umumnya sejalan dengan laju urbanisasi dan bertambahnya jumlah penduduk (Widiawaty dkk., 2018.). Salah satu wilayah perkotaan di Jawa Barat yang mengalami perkembangan pesat adalah Kota Cirebon yang berperan sebagai core region bagi Ciayumajakuning (Dede dkk., 2016; Ati dkk., 2017). Peranan tersebut membuat Kota Cirebon mengalami peningkatan laju alih fungsi lahan hingga menjalar menuju sub-urban. Area yang semula didominasi oleh lahan bervegetasi dikonversi menjadi lahan terbangun untuk pemukiman, industri, amenities maupun prasarana transportasi demi memenuhi kebutuhan masyarakat urban yang ditambah dengan pemakaian material kontruksi yang dapat menyerap panas serta memiliki kapasitas albedo rendah (Widiawaty dkk., 2018; Skelhorn dkk., 2016; Sailor, 2006). Selain itu, dampak peningkatan suhu udara di Kota Cirebon semakin bertambah buruk bila berpadu dengan bertiupnya angin Kumbang selama periode musim kemarau.

Kajian terhadap dinamika suhu udara dan kerapatan vegetasi di Kota Cirebon perlu diperhatikan dengan seksama karena berkaitan dengan urban resilence. Secara spasial, pengamatan keduanya dapat dilakukan secara efektif dan efisien dengan memanfaatkan data citra satelit penginderaan jauh yang memiliki resolusi multi-temporal dan multi-spektral (Sencaki dkk., 2013). Estimasi suhu permukaan (LST) diperoleh dari saluran (band) termal yang dianalisis menggunakan radiative transfer equation, sedangkan informasi kerapatan vegetasi diperoleh melalui normalized difference vegetation index (NDVI) yang melibatkan band inframerah jarak dekat (NIR) (Nugroho dkk., 2016). Kedua informasi ini juga dapat digunakan untuk analisis fenomena urban heat island. Oleh sebab itu, penelitian ini bertujuan untuk menganalisis dinamika suhu permukaan dan kerapatan vegetasi di Kota Cirebon selama periode 20 tahun.

\section{METODE PENELITIAN}

Penelitian ini berlokasi di Kota Cirebon, Provinsi Jawa Barat, Indonesia. Kota Cirebon memiliki luas $37.36 \mathrm{~km}^{2}$ yang terbagi atas lima kecamatan dan 22 kelurahan (Anshari dkk., 2017). Wilayah ini merupakan kotamadya yang berbatasan langsung dengan Laut Jawa serta dikelilingi Kabupaten Cirebon (Gambar 1). Kota Cirebon merupakan region megathermal dengan curah hujan 1000 - 2000 $\mathrm{mm}$ per tahun serta dilalui angin jatuh dari Pegunungan Kumbang (BPS Kota Cirebon, 2018). Daya tarik Kota Cirebon sebagai lokasi perdagangan dan pemerintahan memicu terjadinya urbanisasi dan perluasan wilayah mulai gementee, kotapraja, hingga kotamadya seperti sekarang. Dinamika tersebut juga berdampak pada perubahan suhu udara dan lahan bervegetasi.

\subsection{Akuisisi Data}

Pengamatan dinamika suhu permukaan dan kerapatan vegetasi di Kota Cirebon selama 20 tahun terbagi atas tiga waktu yakni 1998, 2008, dan 2018. Penelitian ini memanfaatkan citra satelit Landsat-5 TM dan Landsat-8 OLI yang diperoleh dari USGS, sedangkan validator data berasal dari citra satelit MODIS Terra / Aqua dari NOAA yang memiliki konstanta konversi DN 0.02 (Tabel 1). Pemilihan sumber data penelitian didasari atas parameter spasial, temporal, spektral, dan ketersediaan data pada periode yang sama. Selain itu, data citra satelit Landsat dan MODIS memiliki keunggulan lain yakni bersifat terbuka dan dapat diakses secara daring (online). 


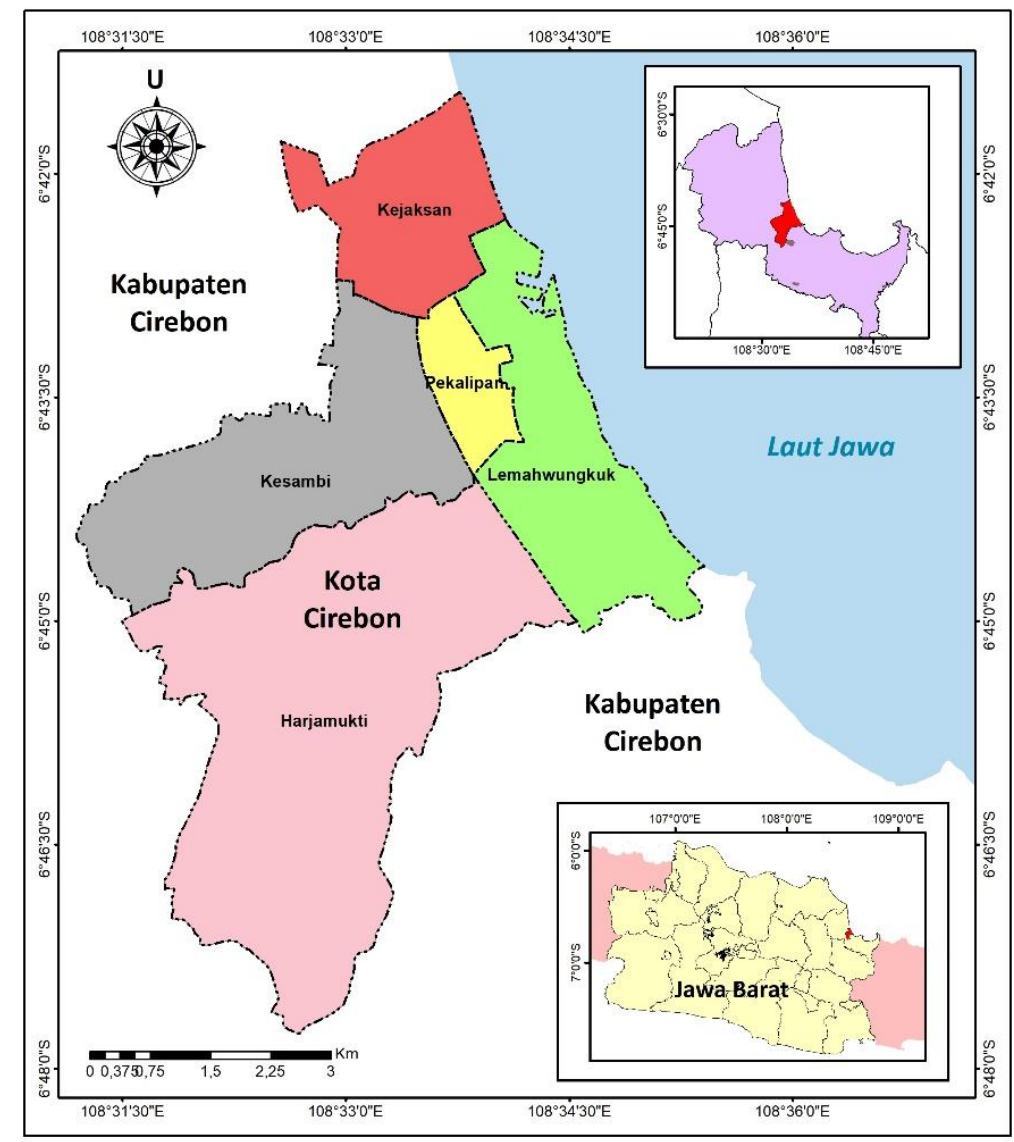

Gambar 1. Lokasi Kajian.

Tabel 1. Data Penelitian.

\begin{tabular}{lllll}
\hline \multicolumn{1}{c}{ Dataset } & \multicolumn{1}{c}{ Band } & \multicolumn{1}{c}{ Resolusi } & \multicolumn{1}{c}{ Kriteria } & \multicolumn{1}{c}{ Sumber } \\
\hline Landsat-5 TM & Band - Thermal (B6) & $120(30) \mathrm{m}$ & $\begin{array}{l}\text { AOI memiliki } \\
\text { tutupan awan }<5\end{array}$ & $\begin{array}{l}\text { Earth Explorer } \\
\text { USGS }\end{array}$ \\
& Band - Red (B3) & $30 \mathrm{~m}$ & $30 \mathrm{~m}$ & persen \\
& Band - NIR (B4) & $100(30) \mathrm{m}$ & AOI memiliki & Earth Explorer \\
Landsat-8 OLI & Band - Thermal (B11) & $100(30) \mathrm{m}$ & $\begin{array}{l}\text { tutupan awan }<5 \\
\text { persen }\end{array}$ & USGS \\
& Band - Thermal (B12) & 100 & \\
& Band - Red (B4) & $30 \mathrm{~m}$ & & \\
MODIS & Band - NIR (B5) & $30 \mathrm{~m}$ & & GSFC Earthdata \\
Terra / Aqua & LST (MOD11) & $1000 \mathrm{~m}$ & $\begin{array}{l}\text { AOI memiliki } \\
\text { tutupan awan }<5\end{array}$ & NASA \\
& NDVI (MOD13) & $250 \mathrm{~m}$ & persen & \\
\hline
\end{tabular}

\subsection{Teknik Analisis Data}

Sebelum diolah untuk analisis suhu permukaan dan kerapatan vegetasi, data citra satelit memerlukan tahapan pre-processing yang terdiri atas koreksi geometrik, radiometrik, dan atmosferik. Tahapan ini berguna untuk mendapatkan niai akurasi spasial dan spektral terbaik dari masingmasing citra. Penentuan nilai suhu permukaan
(LST) diperoleh dengan menggunakan radiative transfer equation (Tan, dkk., 2009) sebagai berikut.

$$
L_{\lambda}=M_{L} \times Q_{c a l}+A_{L}
$$


dimana $\mathrm{L}_{\lambda}$ merupakan nilai radiasi spektral TOA, $\mathrm{M}_{\mathrm{L}}$ sebagai faktor rescaling band termal, $\mathrm{Q}_{\text {cal }}$ besaran energi kalor, dan $\mathrm{A}_{\mathrm{L}}$ menunjukkan nilai konstanta band termal.

Nilai radiasi spektral selanjutnya dikonversi menjadi suhu kecerahan dengan mengacu pada metadata tiap dataset masing-masing untuk citra satelit, nilai suhu kecerahan dapat digunakan sebagai acuan LST. Konversi nilai radiasi spektral mengacu pada persamaan 2 .

$$
\mathrm{T}=\frac{K_{2}}{\ln \left(\frac{K_{1}}{L_{\lambda}}+1\right)}
$$

dimana T merupakan nilai suhu dalam satuan Kelvin, $\mathrm{K}_{2} / \mathrm{K}_{1}$ sebagai konstanta kalibrasi yang dperoleh dari metadata, $\mathrm{L}_{\lambda}$ adalah nilai radiasi spektral dari persamaan 1 .

Setelah nilai suhu permukaan diketahui dan telah dikonversi dalam satuan derajat Celsius, penentuan nilai kerapatan vegetasi dengan metode NDVI melibatkan kanal (band) merah (red) dan inframerah jarak dekat (NIR). Nilai NDVI dapat diketahui melalui persamaan 3.

$$
\mathrm{NDVI}=\frac{\text { NIR band }- \text { Red band }}{\text { NIR band }+ \text { Red band }}
$$

Nilai NDVI dibawah 0 menunjukkan badan air, nilai $0-0.2$ merupakan lahan terbangun dengan kerapatan vegetasi yang minim, sedangkan nilai $0.2-0.4$ menunjukkan area bervegetasi campuran (Tan dkk., 2009; Utomo dkk., 2017). Semakin tinggi nilai NDVI menunjukkan tingginya nilai kerapatan vegetasi di suatu area yang mana nilai $>0.4$ dinyatakan sebagai fully vegetatated. Sementara itu, korelasi spasial antara nilai suhu permukaan dan kerapatan vegetasi dapat diperoleh dengan metode band collection statistics karena data penelitian memiliki distribusi normal (Dede dkk., 2018). Metode ini melibatkan nilai kovarian antar-layer sebagai basis bagi penentuan nilai korelasi yang mengacu pada dua persamaan berikut.

$$
\begin{aligned}
& \operatorname{Cov}_{i, j}=\frac{\left(z_{i k}-\mu_{i}\right)-\left(z_{j k}-\mu_{j}\right)}{N-1} \\
& \operatorname{Corr}_{i, j}=\frac{\operatorname{Cov}_{i, j}}{\delta_{i} \delta_{j}}
\end{aligned}
$$

dimana $\operatorname{Cov}_{\mathrm{i}, \mathrm{j}}$ merupakan nilai kovarian layer i maupun $\mathrm{j}$, z sebagai nilai LST atau NDVI tiap sel, $\mu$ menunjukkan nilai rata-rata, $\mathrm{N}$ sebagai jumlah sel, Corr $_{i j}$ sebagai nilai korelasi antar-layer, dan $\delta$ adalah nilai standar deviasi.

Akurasi pengamatan suhu permukaan dan kerapatatan vegetasi dari citra Landsat diperoleh dengan cara membandingkan kedua nilai tersebut dengan hasil dari citra MODIS Terra / Aqua, hal ini sesuai dengan mekanisme pengujian data pengolahan citra penginderaan jauh secara terselia melalui pendekatan statistika (Widiawaty., 2019). Pengujian kedua data dilakukan dengan metode Uji-F yang memanfaatkan data hasil analisis kovarian karena data memenuhi kaidah statistik parametris, kesamaan hasil ditunjukkan bila nilai F-hitung < F-tabel.

\section{HASIL DAN PEMBAHASAN}

Pada tahun 1998 suhu permukaan (LST) ratarata Kota Cirebon mencapai $29.19{ }^{\circ} \mathrm{C}$. Nilainya terus berubah menjadi $30.31{ }^{\circ} \mathrm{C}$ pada tahun 2008 dan $30.37{ }^{\circ} \mathrm{C}$ pada tahun 2018 . Tabel 2 menunjukkan suhu permukaan ratarata di Kota Cirebon selama 20 tahun mengalami peningkatan sebesar $1.18^{\circ} \mathrm{C}$. Pada periode 1998 - 2008 kenaikan suhu permukaan mencapai $1.12{ }^{\circ} \mathrm{C}$, sedangkan kenaikan suhu permukaan lebih rendah terjadi pada periode 2008 - 2018 yakni sebesar 0.06 ${ }^{\circ} \mathrm{C}$. Suhu permukaan di Kota Cirebon memiliki pola distribusi yang memusat dan terus menurun menuju wilayah sub-urban. Lokasi dengan suhu permukaan yang lebih tinggi umumnya berupa central business district (CBD), area industri, pelabuhan, titik rawan kemacetan (traffic jam), dan terminal. Dinamika suhu permukaan juga menunjukkan adanya peningkatan rasio wilayah dengan suhu tinggi, dimana pada tahun 2018 wilayah yang memiliki suhu permukaan $>30{ }^{\circ} \mathrm{C}$ mencapai 71.7 persen atau $28.7 \mathrm{~km}^{2}$ (Gambar 2 dan 3).

Perubahan yang dinamis tidak hanya dialami oleh suhu permukaan, tetapi juga kerapatan vegetasi di Kota Cirebon. Kerapatan vegetasi rata-rata mengalami penurunan yang berarti selama periode 1998 - 2008. Fenomena tersebut dapat dijumpai pada Kecamatan Harjamukti dan Kecamatan Kesambi yang 
merupakan konsentrasi area industri serta padat transportasi seperti yang ditunjukkan pada Gambar 3. Pada tahun 2018, kerapatan vegetasi yang sangat tinggi (NDVI > 0.40) di Kota Cirebon hampir tiada karena hanya menyisakan 0.2 persen atau $0.077 \mathrm{~km}^{2}$, padahal pada 20 tahun yang lalu eksistensinya mencapai 31.9 persen atau $12.76 \mathrm{~km}^{2}$. Dinamika ini menunjukkan adanya alih fungsi lahan menjadi build-up area akibat pertumbuhan jumlah penduduk maupun urban sprawl (Sobrino dkk., 2004).

Dinamika suhu permukaan dan kerapatan vegetasi di Kota Cirebon terindikasi memiliki sebaran yang saling berhubungan. Hasil uji korelasi spasial antara keduanya selama periode 1998 - 2018 memiliki nilai -0.284 dengan tingkat signifikansi 0.05 . Hal ini membuktikan nilai suhu permukaan dan kerapatan vegetasi saling bertolak belakang, dimana fenomena suhu yang tinggi dapat dijumpai pada area dengan kerapatan vegetasi rendah dan vice versa. Korelasi negatif yang lebih kuat terjadi pada tahun 1998 dan terus melemah hingga sekarang seperti yang disajikan pada Tabel 3. Sementara itu, baik suhu permukaan maupun kerapatan vegetasi mengalami korelasi yang positif dengan periode sebelumnya, dimana peningkatan nilai kedua fenomena ini terjadi secara lokal dan bersamaan dengan efek yang menjalar (Zullo dkk., 2019). Efek seperti ini mudah ditemui pada area yang mengalami peningkatan aktivitas manusia (Koto, 2015).

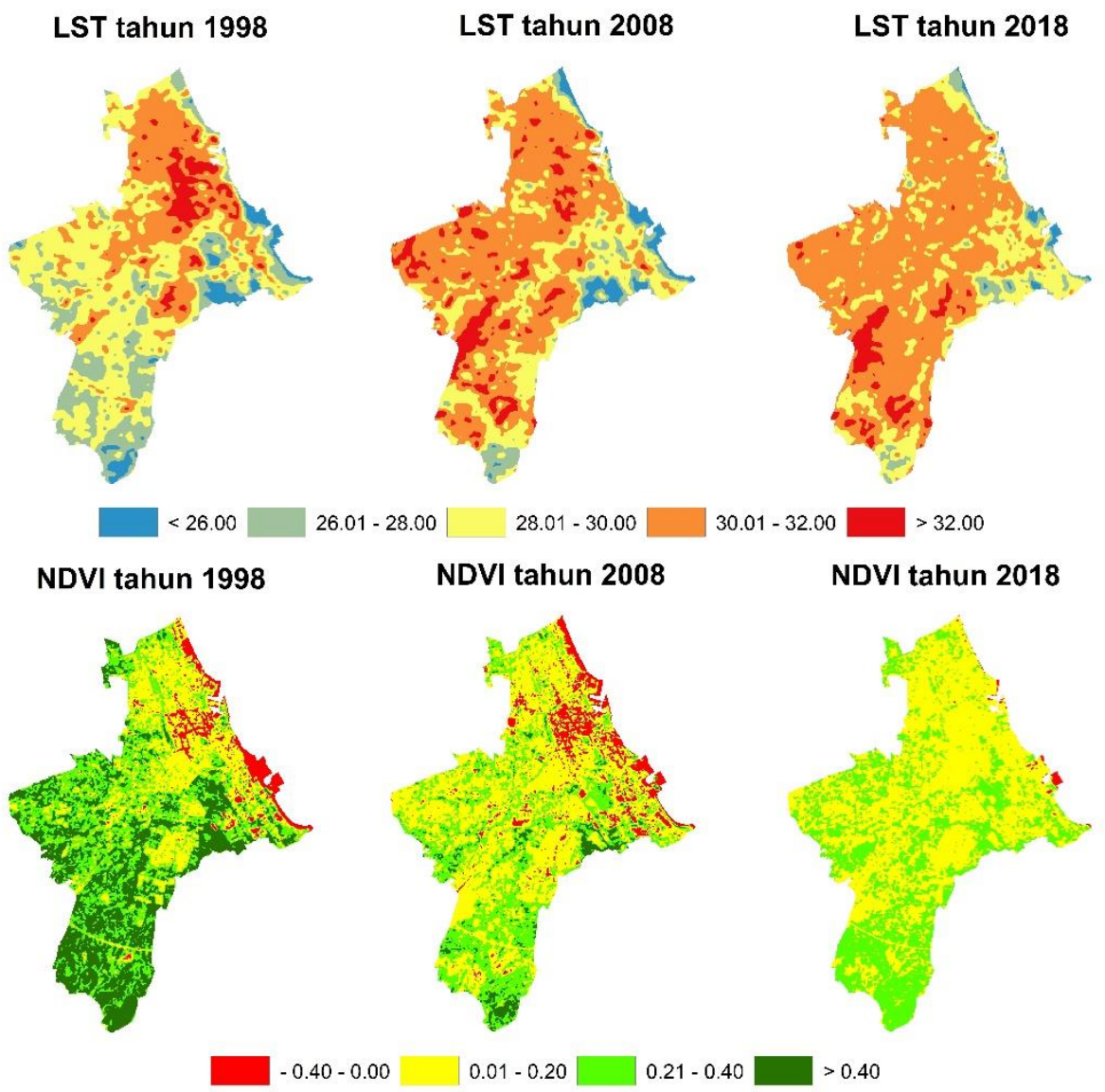

Gambar 2. Dinamika spasial suhu permukaan (LST) dan kerapatan vegetasi (NDVI).

Tabel 2. Dinamika suhu permukaan (LST) dan kerapatan vegetasi (NDVI) selama 20 tahun.

\begin{tabular}{lccccccccc}
\hline LST & Min. & Maks & Rerata & Std.Dev & NDVI & Min. & Maks & Rerata & Std.Dev \\
\hline 1998 & 20.32 & 35.01 & 29.19 & 1.77 & 1998 & -0.40 & 0.67 & 0.28 & 0.18 \\
2008 & 20.15 & 35.48 & 30.31 & 1.84 & 2008 & -0.41 & 0.64 & 0.16 & 0.13 \\
2018 & 22.31 & 34.94 & 30.37 & 1.28 & 2018 & -0.19 & 0.46 & 0.17 & 0.08 \\
\hline
\end{tabular}



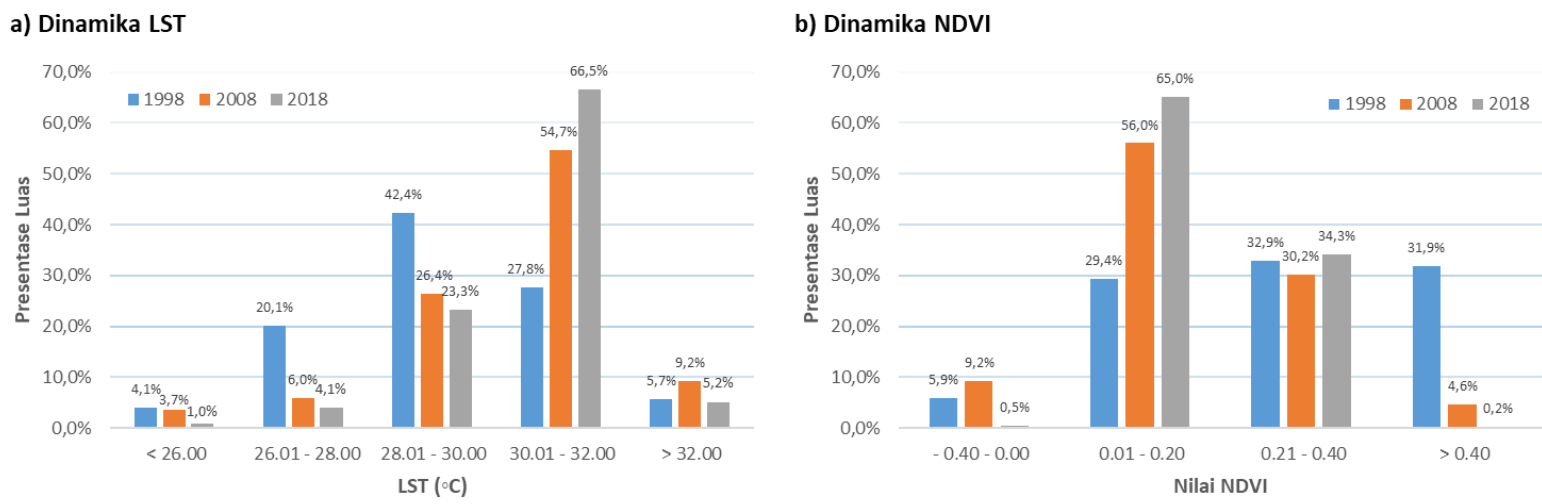

Gambar 3. Perbandingan luas suhu permukaan (LST) dan kerapatan vegetasi (NDVI).

Tabel 3. Hubungan (korelasi) antara suhu permukaan (LST) dan kerapatan vegetasi (NDVI).

\begin{tabular}{lrrrrrr}
\hline & LST 2018 & NDVI 2018 & LST 2008 & NDVI 2008 & LST 1998 & \multicolumn{1}{c}{ NDVI 1998 } \\
\hline LST 2018 & 1 & -0.13784 & 0.83429 & -0.10067 & 0.47793 & 0.06991 \\
NDVI 2018 & -0.13784 & 1 & -0.17643 & 0.72696 & -0.44034 & 0.63224 \\
LST 2008 & 0.83429 & -0.17643 & 1 & -0.21122 & 0.59802 & -0.02152 \\
NDVI 2008 & -0.10067 & 0.72696 & -0.21122 & 1 & -0.40017 & 0.69617 \\
LST 1998 & 0.47793 & -0.44034 & 0.59802 & -0.40017 & 1 & -0.50494 \\
NDVI 1998 & 0.06991 & 0.63224 & -0.02152 & 0.69617 & -0.50494 & 1 \\
\hline
\end{tabular}

Pengamatan dinamika suhu permukaan dan kerapatan vegetasi dengan citra Landsat memiliki akurasi yang baik. Berdasarkan hasil uji beda (Uji-F) dengan memanfaatkan data citra MODIS Terra / Aqua, nilai suhu permukaan dan kerapatan vegetasi memiliki nilai variansi yang sama. Komparasi antara suhu permukaan dari citra Landsat dan LST MODIS mempunyai nilai F-hitung 0.931 yang lebih rendah dari nilai F-tabel yang mencapai 4.091. Sementara itu, nilai kerapatan vegetasi dari citra Landsat juga memiliki hasil yang serupa dengan citra MODIS karena hasil komparasi varians nilainya menunjukkan nilai F-hitung yang lebih kecil dari $(1.265<4.065)$. Oleh sebab itu, baik citra Landsat maupun MODIS dapat dimanfaatkan secara bersamasama dalam pengamatan dinamika suhu permukaan dan kerapatan vegetasi di Kota Cirebon, mesikpun kedua citra tersebut memiliki resolusi spasial yang berbeda.

Dinamika peningkatan nilai suhu permukaan yang selaras dengan menurunnya tingkat kerapatan vegetasi di Kota Cirebon menunjukkan interaksi antara kondisi lingkungan dan fenomena klimatik. Tren kenaikan suhu permukaan memiliki multiplier effect bagi lingkungan maupun manusia berupa masalah kesehatan, meningkatkan konsumsi daya listrik, terganggunya keseimbangan ekologis, kegagalan panen, hingga urban heat island. Adanya interaksi yang kuat antara suhu permukaan dan kerapatan vegetasi menunjukkkan solusi penanganan kenaikan suhu secara tepat dapat melalui berbagai program penghijauan seperti restorasi taman kota, green belt, reforestrasi sempadan sungai maupun mangrove di pinggir pantai, serta menumbuhkan kesadaran masyarakat urban untuk memiliki roof garden maupun menghijaukan pekarangan di sekitarnya (Peng dkk., 2014). Dari segi regulasi, penataan kawasan industri, pengawasan alih fungsi lahan, pengaturan transportasi, hingga pemakaian material konstruksi yang memiliki albedo tinggi perlu dikuatkan kembali agar kenaikan suhu permukaan dapat dikendalikan.

\section{KESIMPULAN}

Suhu permukaan dan kerapatan vegetasi di Kota Cirebon pada periode 1998-2018 mengalami dinamika yang berbeda. Suhu permukaan mengalami peningkatan rata-rata sebesar $1.18^{\circ} \mathrm{C}$, sedangkan kerapatan vegetasi rata-rata semakin menurun. Secara spasial, area bersuhu tinggi tersebar semakin meluas yang diringi dengan berkurangnya area 
bervegatasi rapat di Kota Cirebon. Suhu permukaan dan kerapatan vegetasi berkorelasi secara negatif dan signifikan. Fenomena ini menunjukkan berkurangnya vegetasi berdampak pada peningkatan suhu permukaan yang dalam jangka panjang mampu memberikan beragam efek negatif bagi lingkungan maupun manusia. Oleh sebab itu, penguatan kembali kesadaran masyarakat dan pihak terkait dalam menanggulanginya perlu ditingkatkan.

\section{UCAPAN TERIMA KASIH}

Penulis mengucapkan terima kasih yang sebesar-besarnya kepada USGS dan NASA sebagai penyedia open data untuk citra satelit Landsat series dan MODIS Terra / Aqua. Penelitian ini tidak dapat terlaksana berkat bantuan gagasan, dana, dan kerjasama yang apik di antara penulis secara swadaya. Tak lupa penulis mengucapkan terima kasih juga kepada Nurhanifah (Pendidikan Geografi UPI 2016) atas segala informasi terkait publikasi serta seluruh pihak yang tidak dapat disebutkan satu per satu.

\section{DAFTAR PUSTAKA}

Anshari, B., Dede, M., Tirtaya, R. dan Tiryadi. 2017. Kajian Etnosemantik dalam Toponimi Wilayah Kabupaten dan Kota Cirebon. Prosiding Seminar Internasional Leksikologi dan Leksikografi 2017, Vol. 1, pp.64-69. FIB Universitas Indonesia. Depok. (https://doi.org/10.17605/OSF.IO/NT Q48).

Ati, A., dkk. 2017. Socio-Cultural and Environmental Aspects on Toponymy System of Villages in The East Region of Cirebon. Proceeding 2nd ICSE 2017. Vol. 1, pp. 150-156. (https://dx.doi.org/10.5220/00070945 01500156).

BPS Kota Cirebon. 2018. Kota Cirebon dalam Angka 2018. BPS. Cirebon.

Dede, M., Sewu, R. S. B., Yutika, M., dan Ramadhan, F. 2016. Analisis Potensi Perekonomian Sektor Pertanian, Kehutanan, dan Perikanan serta Pertambangan dan Penggalian di Pantura Jawa Barat. Prosiding
Seminar Nasional Geografi (Epicentrum 5.5), Vol. 1, pp. 100-108. (https://doi.org/10.17605/OSF.IO/M C2T6).

Dede, M., Sugandi, D., dan Setiawan, I. 2018. Pengaruh Kondisi Lingkungan Terhadap Kerawanan Kejahatan di Kawasan Perkotaan Studi Kasus di Kecamatan Sumur Bandung, Kota Bandung. Prosiding Seminar Nasional Geomatika 2018, Vol. 3, pp. 555-564. Badan Informasi Geospasial. Bogor. (http://dx.doi.org/10.24895/SNG.201 8.3-0.1009).

Govaerts, B. dan Verhulst, N. 2010. The Normalized Difference Vegetation Index (NDVI) GreenSeekerTM Handheld Sensor: Toward the Integrated Evaluation of Crop Management. CIMMYT. Mexico City.

Koto, A. G. 2015. Analisis Suhu Permukaan Kota Gorontalo dan Sekitarnya Menggunakan Saluran Thermal Citra Landsat 7 ETM. Prosiding Seminar Nasional Penginderaan Jauh 2015, Vol. 1, pp. 336-342.

Lin, X. S., Tang, J., Li. Z, Y. dan Li, H. Y. 2016. Vegetation Greenness Modelling in Response to Interannual Precipitation and Temperature Changes Between 2001 and 2012 in Liao River Basin in Jilin Province, China. Springerplus, Vol. 5, No. 1. p.1173.

Nandi dan M. Dede. 2019. Urban Heat Island Assessment Using Remote Sensing Data in West Java. The 1st International Conference on Education, Science and Technology (ICESTech) 2019. Konaspi dan UNP. Padang.

Nugroho, S. A., Wijaya, A. P., dan Sukmono, A. 2016. Analisis Pengaruh Perubahan Vegetasi Terhadap Suhu Permukaan Di Wilayah Kabupaten Semarang Menggunakan Metode Penginderaan Jauh. Jurnal Geodesi UNDIP, Vol. 5, No. 1, pp. 253-263. 
Peng, S., dkk. 2014. Afforestation in China Cools Local Land Surface Temperature. Proc. Natl. Acad, Sci. USA, Vol. 111, No. 8, pp. 2915-2919. (https://dx.doi.org/10.1073\%2Fpnas. 1315126111).

Sailor, D. J. 2006. Mitigation of Urban Heat Islands - Recent Progress and Future Prospects. Proceeding of 6th Symposium on the Urban Environment and Forum on Managing our Physical and Natural Resources. AMS. Atlanta, GA. (https://pdfs.semanticscholar.org/28b 3/9def355d1da59b34797b678321764 78b3311.pdf).

Sencaki, D. B., Sukotjo, B. M., dan Wahyu, U. 2013. Analisa Relasi Perubahan Tutupan Lahan dan Suhu Permukaan Tanah di Kota Surabaya Menggunakan Citra Satelit Multispektral Tahun 1994 - 2012. Jurnal Teknik Pomits, Vol. 2, No. 1, pp. 1-6.

Skelhorn, C. P., Geoff. L. dan Lindleya, S. J. 2016. Impacts on Cooling Energy Consumption Due to the UHI and Vegetation Changes in Manchester, UK. Energy and Building, Vol. 122, No. 15, pp. 150-159 (https://doi.org/10.1016/j.enbuild.201 6.01.035).

Sobrino, J. A., Jiménez-Muñoz, J. C., dan Paolini, L. 2004. Land Surface Temperature Retrieval from Landsat TM 5. Remote Sensing of Environment, Vol. 90, No. 4, pp. 434440.

Tan, K. C., Lim, H. S., Jafri, M. Z. M. dan Abdullah, K. 2009. Study on Land Surface Temperature Based on Landsat Image Over Penang Island, Malaysia. Proceeding of Sixth International Conference on Computer Graphics, Imaging and Visualization. IEEE. Tianjin. (https:// 10.1109/CGIV.2009.94)

Utomo, A. W., Suprayogi, A., dan Sasmito, B. 2017. Analisis Hubungan Variasi Land Surface Temperature dengan Kelas Tutupan Lahan Menggunakan
Data Citra Satelit Landsat (Studi Kasus : Kabupaten Pati). Jurnal Geodesi UNDIP, Vol. 6, No. 2, pp. 71-80.

Widiawaty, M. A. 2019. Mari Mengenal Sains Informasi Geografis. Aria Mandiri Group. Bandung.

Widiawaty, M. A., Dede, M. dan Ismail, A. 2018. Analisis Tipologi Urban Sprawl di Kota Bandung Menggunakan Sistem Informasi Geografis. Prosiding Seminar Nasional Geomatika 2018, Vol. 3, pp. 547-554. Badan Informasi Geospasial. Bogor. (http://dx.doi.org/10.24895/SNG.201 8.3-0.1007).

Widiawaty, M. A., Pramulatsih, P. dan Febriani, V. 2018. Jaringan Transportasi dan Pengembangan Destinasi Pariwisata di Kota Cirebon. Proceeding Book The 6th Travel Industry Student Forum, 1, pp. 127148. Sekolah Tinggi Pariwisata Bandung. Bandung. (https://doi.org/ 10.31227/osf.io/qsngx).

Zarzoso, M. dan Maruotti, A. 2011. The impact of Urbanization on $\mathrm{CO} 2$ Emissions: Evidence from Developing Countries. Ecol. Econ., Vol. 70, No. 7, pp. 1344-1353, (https://doi.org/10.1016/j.ecolecon.20 11.02.009)

Zhang, X. X, Wu, P. F, dan Chen, B. 2010. Relationship between Vegetation Greenness and Urban Heat Island Effect in Beijing City of China. Procedia Environmental Sciences, Vol. 2, pp. 1438-1450. (https://doi.org/10.1016/j.proenv.201 $0.10 .157)$.

Zullo, F., dkk. 2019. Effects of Urban Growth Spatial Pattern (UGSP) on the Land Surface Temperature (LST): A Study in the Po Valley (Italy). Science of The Total Environment, Vol. 650, No. 2, (https://doi.org/10.1016/j.scitotenv.2 018.09.331). 